\title{
The Synergy of School and Madrasah Diniyah in Implementing Full Day School
}

\author{
Riyono Riyono \\ Magister Manajemen Pendidikan Islam \\ Universitas Muhammadiyah Sidoarjo. \\ Sidoarjo, Indonesia \\ riy_sdm1gempol@yahoo.com
}

\begin{abstract}
This study aims to describe the synergy pattern built between schools and madrasah diniyah in applying full day school. Schools and madrasahs are two different entities in the education system in Indonesia. Yet, in the end, it can be synergized in the form of full day school. This research includes qualitative research with phenomenological approach. The data collection techniques used are interviews, observations and documents, whereas the data analysis used is Miles and Hubberman analysis model which involves data reduction, data presentation and conclusion. The conclusion of this study illustrates the synergy pattern between school and madrasah diniyah materialized in the form of cooperation in implementing madrasah diniyah school. The cooperation in question is creative and mutually beneficial to both parties. The implication of this study provides a full day school model by combining the school and madrasah diniyah.
\end{abstract} school

Keywords-full day; madrasah diniyah; school; synergy;

\section{INTRODUCTION}

This research is inspired by some parties rejection due to the Ministry of Education and Culture's regulation (Permendikbud) No 23 year 2017 on Character Education Strengthening (Penguatan Pendidikan Karakter-PPK) at school. One of its implementation is about the chage of school days from six to five days. Consequently there is also a change of student learning hours so that they have to come home a little late in the afternoon.

The implementation of that Permendikbud is feared to reduce the existence of religious-patterned education such as Madrasah Diniyah and Qur'an Education Institution (Taman Pendidikan Qur'an-TPQ). This is understandable because they assume with five school days, students will be in school longer so that the time to study in TPQ and Madin can be eroded.

On the other hand, some local governments in Indonesia stated the local or the regent regulations that students in that area must follow the education of madrasah diniyah. One of the regulation points require the students to follow Madin as one of the qualification to continue their study to the higher education level.

Madrasah is one of the Islamic education institutions other than boarding schools and Islamic schools [1].
Referring to Regulation of the Minister of Religious Affairs of the Republic of Indonesia number 13 of 2014, there are several types of diniyah education; formal, informal and nonformal [2].

In Article 46 paragraph 1, Madrasah Diniyah Takmiliyah is one of the levels of non formal diniyah education organized by the community. Madrasah diniyah Takmiliyah has curriculum structure and level as education in general. The levels are ula (Primary School-SD/MI), wustha (Junior High School-SMP/MTs), ulya (Senior High School-SMA/SMK/MA/MAK) and al-jami'ah (Higher Education). The taught curriculum includes: a) aqidah, b) hadith, c) fiqh, d) morality, and e) Arabic [3] [4].

Fundamentally, many Islamic schools have already implemented a full day school system. Full day school is a school that implements the hours of learning from morning till evening [5]. Another opinion says that full day school is a school that combines learning and playing time for children within 5 working days where the students stay at school longer than regular school [6]. Noorhaidi Hasan defines Full Day School as a system which requires students in elementary (grade 3-6) to attend from 07:00 to 15:00 [7]. The full day school curriculum mostly combines general and religious education by modifying the national curriculum and adding the learning hours [8].

Full day school or also called All Day School [9] originallycame from the United States in 1980 treated in kindergarten and then increased to the level of elementary to high school. The factor emergence full day school was because many women worked outdoors while they had small children. This situation made them have no time to supervise their children. In Indonesia, full day school began to develop since 1990 pioneered by private schools, including the Islamic schools [10] founded by Muhammadiyah, Maarif NU, JSIT, Hidayatullah and many others [11].

As an idea in the education world, full day school has advantages and disadvantages. The advantages of full day school system include: a) full school power accommodate working parents b) There is plenty of time for families c) Minimize the negative environmental impact on students. d) Hildebrand's research concluded, full-day school students 
had better reading achievements than those who had a halfday school [12]. e) PISA (Program for International Student Assessment) survey result states that countries that implement full day school are high ranked [13].

In contrary, the weaknesses of full day school include students are easily bored with the school environment; students are less interacting with the family environment; reducing students' play time, students lose much time to learn at home and learn about living with their family [14].

Madins and schools are two different entities. School is a formal education while Madin is a non formal education. However, in the practice of full day school, the two entities can be synergized. The synergy of schools and madins certainly does not happen without intensive communication between the two parties to formulate synergies itself.

Synergy comes from the Greek syn-ergo which means to cooperate [15]. According to Walton, synergy is the result of efforts of 'co-operative effort' or cooperation, therefore the important thing to produce a good synergy is cooperation [16]. Murat Gürkan Gülcan calls synergy as the effect of the interaction of two or more factors. This is based on the saying "two heads are better than one." Deardorff Dale and Williams Greg, interpret synergies as collective thinking of two or more people to benefit jointly from the ideas gained [17].

Covey uses the term synergy in a communication relationship formed from the integration of a high level of cooperation spirit and a relationship of mutual trust. This synergy is a creative process built jointly on the basis of mutual trust and high spirit of cooperation. According to Covey, a synergistic communication is constructed from courage and assertiveness, with also high consideration [18]. In line with Covey, Hartanto defines synergy as a new idea, generated from a variety of ideas put forward by many parties, based on new concepts or mindsets [19].

From the above definitions, it can be concluded that synergy is a creative relationship built together by two or more people based on mutual trust and high spirit of cooperation. The goal is to gain energy, new thinking or innovative ideas. Simply, a synergistic interaction involves the following elements: 1) cooperation, 2) result/benefit, and 3) mutual trust.

Based on the background above, this research describes the form of synergy between school and madrasah diniyah in full day school implementation. The research object is a school that has implemented a full day school system by synergizing the patterns schools as well as madrasah diniyah. The results of this study are expected to provide a full day school model with the synergy pattern of schools and madrasah diniyah. It is also expected to give beneficial contribution to the development of education.

\section{RESEARCH METHODS}

The design used is qualitative research with phenomenological approach. This approach is used to describe the synergy of schools and madrasah diniyah in applying full day school. The synergy of school and madrasah diniyah include the synergy forms or patterns and their beneficial result.

This research was conducted at SD Muhammadiyah 1 Gempol. The school is selected because it has applied the full day school system in collaboration with Madrasah Diniyah Takmiliyah Ula Muhammadiyah al-Falah. The full day curriculum in this school combines the school curriculum with madrasah diniyah takmiliyah ula curriculum from the Ministry of Religion. The subjects of this study were full day school stakeholders, including principals, madrasah diniyah heads, and teachers who are involved in madrasah diniyah.

The data collection techniques include interviews, observation, and documentation. Interview data were obtained by the headmaster, principal of madrasah diniyah and teachers. Observations were made to observe the learning process of madrasah diniyah done in full day school. While the documentation obtained from the data curriculum, lesson schedule, number of teachers and others. Then, the data obtained is analyzed by qualitative data analysis from Miles and Hubberman Model, ie data reduction, data presentation and conclusion drawing. Finally, the validity of data is done by triangulation technique.

\section{RESEARCH FINDINGS AND DISCUSSION}

This section discusses the findings of research on the pattern of the synergy of school and madrasah diniyah in applying full day school. Synergy is a form of cooperation based on mutual trust to get results in the form of creative ideas and benefits.

\section{A. Cooperation}

Describing the synergy pattern means reviewing the pattern of cooperation conducted by schools and madrasah diniyah. Based on the results of interviews with the principal, some information obtained that the desire to apply ful day school has been long existed. But it can only be implemented in the academic year 2016/2017. The idea of implementing full day school is an idea shared by principals, teachers, the Primary and Secondary Education Department (Majelis Dikdasmen) of Muhammadiyah, madrasah and education consultant.

According to the interviews with principals, the implementation of full day school system is based on several factors. First, the school wants to apply a propheticbased holistic education. In other words, the school would like to make the implementation of comprehensive education based on the values taught by the Prophet Muhammad. Secondly, there is a movement trend from agrarian to industrial society, in which, many parents such work outside that they do not have time to take care of their children's education. The society worried the negative inluence affects the unaccompanied children. Third, 
strengthening the school's positioning-difference-branding by considering the idea of full day school is not yet existed in the region. Fourth, the existence of local government regulations that requires students to attend education at madrasah diniyah. From these four things, the full day school system is implemented to the academic year 2016/2017 students limited from the third until the sixth grade.

The cooperation made by schools and madrasah diniyah is to apply full day school to provide education for madrasah diniyah after school learning hours is over. The details of full day school learning activities implementation can be seen in table 1 [20]:

TABLE 1. LEARNING HOURS

\begin{tabular}{|l|l|l|l|}
\hline \multirow{2}{*}{ Learning Period } & \multicolumn{2}{c|}{ Days } \\
\cline { 3 - 4 } & Monday-Thursday & Friday \\
\hline 1 & $07.00-07.45$ & TPQ & Lesson \\
\hline 2 & $07.45-08.20$ & Lesson & Lesson \\
\hline 3 & $08.20-08.55$ & Lesson & Lesson \\
\hline 4 & $08.55-09.30$ & Lesson & Lesson \\
\hline 5 & $09.30-10.00$ & Break & Break \\
\hline 6 & $10.00-10.35$ & Lesson & Lesson \\
\hline 7 & $10.35-11.10$ & Lesson & Lesson \\
\hline 8 & $11.10-11.45$ & Lesson & Friday Prayer \\
\hline 9 & $11.45-12.20$ & Lesson & \\
\hline 10 & $12.20-13.00$ & Break of Prayer Time & Extracurricular \\
\hline 11 & $13.00-14.00$ & Extracurricular & Madrasah diniyah \\
\hline 12 & $14.00-15.30$ & Madrasah diniyah & \\
\hline
\end{tabular}

The table above concludes that the full day implementation takes place from $07.00-15.30$. The implementation of school learning with extra activities completed at 14.00. Afterward, the madrasah diniyah activity is implemented from 14.00 until 15.30. The total hours of madrasah diniyah in school is 1.5 hours per day.

As general full day school, then the school managers designed the learning activities in school from morning until afternoon. The full day school commonly provides additional learning hours with other activities including religious education such as TPQ or madrasah diniyah. Therefore the full day school curriculum is designed by incorporating the curriculum of public school and religious education [21]. The problem that arises later is, how to formulate the curriculum and learning activities in this school. According to the headmaster in the interview, the curriculum and learning activities are designed by combining general education and madrasah diniyah. The model is choosen because the district in question has issued local regulation concerning the obligation of madrasah diniyah. Based on the school curriculum document, the data told that the curriculum used are: 1). Education Unit Level Curriculum (Kurikulum Tingkat Satuan PendidikanKTSP) 2006, 2). local content, 3) Muhammadiyah curriculum such as Islamic education, Muhammadiyah Studies and Arabic (Al Islam, Kemuhammadiyahan dan Bahasa Arab-ISMUBA) and 4) madrasah diniyah curriculum [22]. According to Abdullah's information, the curriculum of madrasah diniyah, specifically, compiled from the curriculum of the Ministry of Religious Affairs.

Information from the principal was then confirmed to the head of the madrasah diniyah. Before the implementation of full day school, he and some madrasah diniyah teachers discussed with the principal. The heads of madrasah diniyah are invited to cooperate to hold madrasah diniyah in school. This call was approved by Abdullah. Because school uses full day system then the implementation of madrasah diniyah is done in school. This is beneficial because it saves the efficiency of the school students, time and energy. In addition, madrasah diniyah also receives the benefit due to the increasing numbers of santri (students). According to the theory of mutual cooperation, this situation is called mutual benefit [23].

Furthermore, the interviews to the principals and the heads of madrasah diniyah resulted the following picture which describes the domain of authority in this joint venture. The points of cooperation between schools and madrasah diniyah can be observed from figure 1:

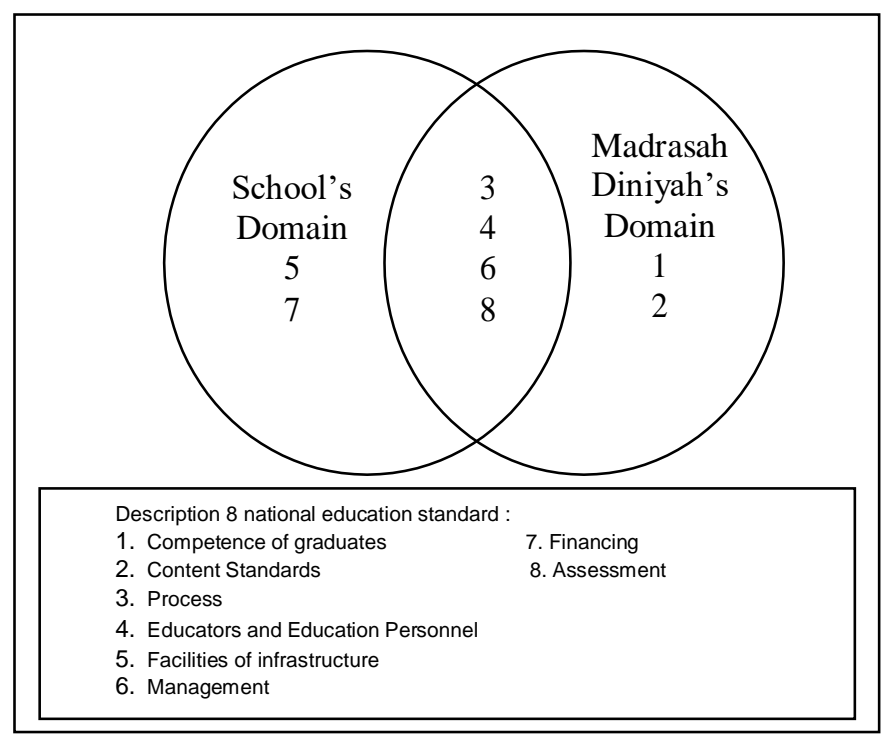

Fig. 1 The domain of school cooperation and madrasah diniyah

Figure 1 presents the domain of cooperation between school and madrasah diniyah based on eight national standards of education. The picture shows clear sharing authorities which involve the joint authority of the two parties, the absolute authority of school and the absolute authority of madrasah diniyah.

The joint authority exists in the learning process, teachers and staffs, management and assessment. In addition, the absolute domain of school concerns in infrastructure and financing. Otherwise, madrasah diniyah has the authority to determine the competence of graduates and content standards.

If we examine the points of cooperation above, then it is concluded that the cooperation between schools and 
madrasah diniyah include the learning process, the promoting tearchers and staffs, management and assessment. It shows that the madrasah diniyah is wellmanaged together with the school. This is considering some matters such as promoting teachers and the learning process are undertaken jointly by two institutions. When it is confirmed to the head of the madrasah diniyah, indeed the points of cooperation say so. There is a synergy of authorities to manage madrasah in schools because of the limited human resources. This condition makes the school put its teachers to teach in madrasah diniyah. The author initially assumes, there is collaboration in the management of madrasah diniyah. Collaborative management of madrasah diniyah in this school is a manifestation of energy that appears according to Najaf Beygi as a form of synergy [24]. This is quickly brought to light because of the formal legal aspects possessed by madrasah diniyah.

The vital problem comes from financing which becomes the absolute domain of school. However, according to the headmaster, all operations involving madrasah diniyah are under the school's responsibility.

Based on the above review, the interaction and communication process of the stakeholder can actually be indicated as a form of synergy. Characteristic formulation of this synergy is the existence of a new thought or idea obtained from the results of interaction and cooperation (cooperative effort). The new idea itself is the idea of full day school implementation. Although the form of synergy is still simple as the formulation of Walton. [25]

The idea that emerged as the result of cooperation in the implementation of madrasah diniyah at school is a good idea. Borrowing Covey's term is referred to as a 'creative cooperation'. Moreover, the form of cooperation generates mutual benefits. Further development of the idea was followed up with the full day school implementation collaboratively in the academic year of 2016/2017. The existence of collaborative cooperation between elements generates new greater energy in the form of mutual benefits, it can be said that the synergy pattern has been formed and run well [26].

\section{B.. Benefits}

Furthermore, the synergy effect of this collaborative process does not stop at implementation only. The results of interviews show the two parties obtains the benefit of the synergy process. From the previous reviews it has been found that the relationship of cooperation built by the schools and madrasah diniyah are mutually beneficial (mutual benefit). The above description is related to the views of Deardorff Dale and Williams Greg, the synergy between schools and madrasah diniyah has to be of benefit [27].

Based on the results of interviews with principals, the benefits gained by the school are: 1). The realization of full day school program 2). Full day school becomes a plus school that generates the school branding. 3). There is a financial addition to the organization of the school.

While the results of interviews with the head of madrasah diniyah, benefits gained on this synergy are: 1). The number of santri increased from twenty to 97, 2). There is additional welfare (salary) for teachers 3 ). Strengthening the existence of madrasah diniyah. 4). The operational costs of madrasah diniyah are covered by the school.

The results of the principal's interview and the special madrasah head of teachers' welfare benefits were then confirmed to the madrasah teachers. According to Adi and Arum, the benefits gained from the synergy of schools and madrasah diniyah is the increase of salary, although not much. More than that, both of them believe they get a reward from God for teaching religion to his students.

\section{Trust each other}

Mutual trust is one part of the synergy that Covey formulates. A synergy based on high trust, often referred to as social capital for the organization [28]. An interesting discovery when interviewing the principal and the head of madin, it turns out that the synergy building between them had never been written.

According to the head of the madrasah diniyah, fellow Muslims must trust each other and it is impossible to betray each other. This statement is in line with the narrative of the school principal saying that the cooperation between schools and madrasah diniyah is done orally.

The pattern of cooperation without basic clear agreement binding like this, if it is unhecked, will cause problems in the future. Considering the position of principal and the head of madin is limited by the time of period. Problems arise for substitutes who are unaware of the form and points of cooperation. Although mutual trust between each other is a good thing, it would be much better if the cooperation does not leave a problem in the future. Therefore, this synergy needs to be done formally with a cooperation agreement. There will be many advantages when cooperation is stated in written rather than verbally.

Finally, by considering 1). The form of cooperation that produces creative ideas in combining school and madrasah diniyah in the concept of full day school. 2). Implementation of full day school which arises the synergy of school and madrasah diniyah, 3). there are benefits for each institution, and 4). the division of authority between schools and madrasah, although only limited to oral, it can be concluded that the pattern of synergy built by the school and madrasah forms creative cooperation and mutual benefit between the two parties.

\section{CONCLUSIONS AND RECOMMENDATIONS}

The this study illustrates that two different educational intitutions, school (formal) and madrasah diniyah (nonformal) can work together in implementing full day school program. The pattern of synergy between the school 
and madrasah diniyah is is excellent manifestation implemented after the school's hour. The results of this study also reject the assumption that the existence of full day school can reduce the existence of religious education unless both can strengthen each other's position in full day school system.

The researcher sugeests any kinds of cooperation can be realized in written form to minimize the unexpected possibilities in the future.

\section{ACKNOWLEDGMENT}

I put my greatest thanks to the Universitas Muhammadiyah Sidoarjo for posting this article.

\section{REFERENCES}

[1] C. Tan, "Educative tradition and islamic schools in Indonesia, J. of Arabic and Islamic Studie,"vol. 1. No. 14, 2014, 50-51. Read too in Imam Bahroni, "The principle of integrated islamic education," Jurnal At-Ta'dib, vol. 9, no. 1, 2014, 2-3

[2] PMA nomor 13 Tahun 2014 tentang Pendidikan Keagamaan Islam, 3

[3] PMA nomor 13 Tahun 2014 tentang Pendidikan Keagamaan Islam, 3

[4] R. Salahuddin, "Kebijakan pengembangan pendidikan al-qur'an di kabupaten pasuruan," J. KMP, vol. 1, no. 2, 2013,212

[5] S. Suranto and S. Septiana, "Penerapan kebijakan full day school terhadap hasil belajar siswa," Makalah Seminar Nasional Pendidikan Universitas Muhammadiyah Surakarta, 2017, Published, 181.

[6] I. Iftayani \& N. Nurhidayati, "Self concept, self esteem and school system," J. Guidance and Counseling, vol. 6, No. 1, 2016, 53

[7] N. Hasan, "Education, young islamists and integrated islamic schools in indonesia," J. Studia Islamika, Vol. 19, no. 1, 2012, 100

[8] R. Tiara, "Pengaruh manajemen pembelajaran full day school terhadap motivasi belajar," J. Manajemen Pendidikan,vol. 23, no. 5, 2012, 437

[9] I.Thoidis and N. Chaniotakis, "All-day school: a school in crisis or a social pedagogical solution to the crisis?," The International Journal of Social Pedagogy, vol 4, no 1, 2015, 143

[10] Y. Yusuf, "Full day school: school excellence model implementation process for a good education," Proc. Ictess UNISRI, vol 1, no. 1, 2017,305

[11] N. Hasan, "Education, young islamists and integrated islamic schools in indonesia," J. Studia Islamika, Vol. 19, no. 1, 2012,91-92

[12] I. Iftayani \& N. Nurhidayati, "Self concept, self esteem and school system," J. Guidance and Counseling, vol. 6, No. 1, 2016, 53-54

[13] I.Thoidis and N. Chaniotakis, "All-day school: a school in crisis or a social pedagogical solution to the crisis?," The International Journal of Social Pedagogy, vol 4, No 1, 2015, 144

[14] N. Hasan, "Education, young islamists and integrated islamic schools in indonesia," J. Studia Islamika, Vol. 19, no. 1,2012,100

[15] A. Mukhtaromi, M.S. Soeaidy, and A. Hayat, "Sinergi pemerintah daerah dan lembaga adat dalam melaksanakan pelestarian kebudayaan," JAP, vol. 1, no.2,wy, 158-159

[16] S. Sulasmi, "Peran variabel perilaku belajar inovatif, intensitas kerjasama kelompok, kebersamaan visi dan rasa saling percaya dalam membentuk kualitas sinergi," J. Ekuitas, vol. 13, no. 2, 2009, 223

[17] M.G. Gülcan, "Complexity theory and new leadership paradigm," British Journal of Education, Society \& Behavioural Science, vol. 10(2), 2015, 7

[18] S. Sulasmi, "Membangun Sinergi dan Moralitas di Lingkungan Organisasi Perguruan Tinggi," Surabaya : Unair, 2010, 3
[19] S. Sulasmi, "Peran variabel perilaku belajar inovatif, intensitas kerjasama kelompok, kebersamaan visi dan rasa saling percaya dalam membentuk kualitas sinergi," J. Ekuitas, vol. 13, no. 2, 2009, 223-227

[20] Data from School Hours of SD Muhammadiyah 1 Gempol, unpublished.

[21] R. Tiara, "Pengaruh manajemen pembelajaran full day school terhadap motivasi belajar," Jurnal Manajemen Pendidikan,vol. 23 , no. 5, 2012, 437

[22] SD Muhammadiyah 1 Gempol, Kurikulum SD Muhammadiyah 1 Gempol Tahun Pelajaran 2017/2018, 2017, unpublished.

[23] P. Jamilah, "Kerjasama PT. Gemilang Unggas Prima Pekanbaru dengan Mitra Peternak J1. Garuda Sakti KM. 21," thesis, UIN Sunan Syarif Kasim Riau, 2015, 25

[24] M.R. Rouniasi, "The principle of synergy; a basic proposal to provide public employment loans, EMT journal, no 2 (6), 2014, 10

[25] S. Sulasmi, "Peran variabel perilaku belajar inovatif, intensitas kerjasama kelompok, kebersamaan visi dan rasa saling percaya dalam membentuk kualitas sinergi," J. Ekuitas, vol. 13, no. 2, 2009, 223

[26] S. Sulasmi, "Peran variabel perilaku belajar inovatif, intensitas kerjasama kelompok, kebersamaan visi dan rasa saling percaya dalam membentuk kualitas sinergi," J. Ekuitas, vol. 13, no. 2, 2009, 223

[27] M.G. Gülcan, "Complexity theory and new leadership paradigm," British Journal of Education, J. Society \& Behavioural Science, vol. $10(2), 2015,7$

[28] S. Sulasmi, “Membangun Sinergi dan Moralitas di Lingkungan Organisasi Perguruan Tinggi," Surabaya : Unair, 2010, 3 